\title{
Optimalisasi Sekolah dalam Menghadapi UNBK Tahun 2019 di SMK Negeri 3 Sukoharjo
}

\author{
Siti Mahmudah $\left.{ }^{*}\right)$, Rahayuning Dyah Dwi Bekti2), Rahmad Febriyan ${ }^{3)}$, \\ Maharani Pamungkas Siwi ${ }^{4}$, Dhany Efita Sari ${ }^{5)}$ \\ 1,2,3,4,5)Universitas Muhammadiyah Surakarta \\ *) sitimahmudah10@yahoo.com
}

\begin{abstract}
Abstrak: Penyelenggaraan ujian nasional berbasis komputer (UNBK) pertama kali diselenggarakan pada tahun 2014. Dari berbagai SMK yang ada di Sukoharjo yang mengikuti UNBK salah satunya adalah SMK Negeri 3 Sukoharjo, dalam persiapan UNBK dipandang dari segi infrastruktur dituntut agar fasilitasnya memadai dari kuantitas ruang yang digunakan, ketersediaan suplai tegangan listrik, sampai pada kebutuhan perangkat komputer yang diperlukan. Dari segi pemahaman materi yang diterima oleh siswa dilakukan pembahasan soal-soal di spm, simulasi, praktek manual dan praktek myob. Semua persiapan ini dilakukan untuk mematangkan para peserta didik,supaya nanti pada waktu pelaksanaaan UNBK berjalan lancar dan meraih nilai baik,serta sarana dan prasarana yang dimiliki sekolah sudah siap.
\end{abstract}

Kata Kunci:UNBK, Optimalisasi Sekolah, Sukoharjo

\section{PENDAHULUAN}

Pendidikan merupakan sektor penggerak pembangunan suatu negara. Pendidikan akan melahirkan sumber daya manusia yang berkualitas, terampil, dan terasah untuk menghadapi berbagai bentuk tantangan zaman. Keberhasilan suatu negara dalam sektor pendidikan akan memberikan angin segar bagi pembangunan (Alawiyah, 2015). Menurunnya mutu pendidikan di Indonesia berdampak terhadap rendahnnya potensi daya saing sumber daya manusianya. Menurut Sastradiharja (2018) penurunan mutu pendidikan disebabkan oleh beberapa faktor, dianataranya adalah perubahan model ujian dari Ujian Nasional Kertas Pensil (UNKP) ke Ujian Nasional Berbasis Komputer (UNBK). Penurunan mutu pendidikan disebabkan karena perubahan sistem pendidikan yang dilakukan secara terus menerus, hal ini menyebabkan penerapan sistem pendidikan yang belum mncapai titik selesai. Salah satu perubahan kebijakan pemerintah dalam dunia pendidikan yaitu pada pelaksanaan evaluasi. Ujian Nasional merupakan suatu bentuk evaluasi pendidikan yang diselenggarakan sebagai amanat dari Undang-Undang Nomor 20 Tahun 2003 tentang Sistem Pendidikan Nasional dalam Pasal 58 Ayat (2).

UNBK merupakan sistem pelaksanaan ujian nasional berbasis komputer yang diselenggarakan oleh pemerintah dengan tujuan untuk meningkatkan kualitas pendidikan utamanya untuk program ujian nasional (Mardiana, 2017). Adanya sistem yang terintegrasi langsung dengan aplikasi-aplikasi pendidikan lainnya seperti DAPODIK, ERaport dan lain sebagainya akan mempermudah sekolah untuk melakukan pelaksanaan kegiatan ujian nasional. Akan tetapi butuh 
sumber daya lebih agar bisa melaksanakan kegiatan UNBK dengan lancar utamanya dari sisi SDM dan juga perangkat pendukung. Menurut Negara (2017) pelaksanaan UNBK masih dirasa cukup berat bagi sekolah-sekolah yang belum terlalu mengenal dan membiasakan pendidikan e-learning. Tidak semua sekolah dapat melaksanakan ujian nasional berbasis komputer, ada beberapa syarat yang harus dipenuhi pinak sekolah untuk dapat melaksanakan UNBK sebagai berikut. 1) pihak sekolah harus mengajukan form kesanggupan untuk melaksanakan UNBK kepada Dinas Pendidikan Provinsi; 2) Dinas Pendidikan Provinsi melakukan pengecekan kelayakan sekolah; dan 3) penetapan sekolah penyelenggara yang didasari Surat Keputusan sekolah lulus uji verifikasi dan dikategorikan layak (Firmansyah, 2018).

Pendidikan harus tetap diperbaharui dan sadar akan perubahan yang bersifat membangun, baik berupa peraturan, sistem maupun teknis dalam pelaksanaan pendidikan. Pelaksaan ujian berbasis komputer juga merupakan salah satu langkah pemerintah dalam mengikuti kemajuan teknologi. Menurut Pakpahan (2016) penggunaan komputer (IT) dalam pelaksanaan ujian nasional memudahkan sistem dengan menciptakan soal yang beragam sehingga sistem penilaian dirasa lebih objektif. Jika evaluasi berada pada indikator baik, maka kualitas pengajaran dan pembelajaran sudah berjalan dengan baik dan berorientasi pada tujuan(Jana, 2019). Namun menurut Sulistyo (2007) dengan Ujian Nasional siswa justru akan belajar seperti mesin yang hanya fokus pada target sementara kemampuan dan tujuan lain terabaikan. Menurut Hidayat (2017) bahkan tidak sedikit siswa yang tidak memiliki target terkait hasil UNBK yang dilaksanakan. Hal ini tentu menimbulkan asumsi bahwa evaluasi dalam pendidikan masih dipertimbangkan manfaat dan tujuannya.

Tujuan UNBK kedepannya adalah menghasilkan lulusan berkualitas dan diharapkan nilai kelulusannya bisa dijadikan dasar untuk jenjang pendidikan berikutnya. Pendapat lain yang berbeda dipaparkan oleh Alawiyah (2015) yang menyatakan bahwa tujuan dari evaluasi melalui Ujian Nasional yaitu 1) bukan untuk menghakimi siswa dengan nilai dan status nilai, namun lebih pada mengevaluasi penyelenggaraan pendidikan di Indonesia; 2) sebagai pertimbangan untuk pemetaan mutu program dan/atau satuan pendidikan berikutnya; serta 3) pembinaan dan pemberian bantuan kepada satuan pendidikan sebagai upaya meningkatkan mutu pendidikan.

Untuk mengatasi pemasalahan tersebut diperlukan suatu sistem simulasi ujian nasional yang perlu diselenggarakan pihak sekolah (Sakethi, 2014). Dalam upaya pengoptimalisasikan UNBK pihak sekolah memberikan pembelajaran komputer kedapa siswa untuk mengantisispasi jika ada siswa yang tidak bisa mengoperasikan komputer, dan memberikan materi ujian secara matang dan terperinci. Siswa sendiri harus memiliki kesadaran untuk bisa mengoperasikan komputer dan melakukan pemahaman lebih terhadap materi yang 
diujikan, agar siswa tidak kesulitan dalam menghadapi ujian yang sebenarnya. Selain itu, pembiasaan penerapan pembelajaran e-learning pada siswa agar memberi kebebasan kepada siswa untuk belajar dan mengeksplorasi diri secara baik (Pakpahan, 2016).

Berdasarkan permasalahan di atas maka dilakukan simulasi ujian nasional oleh SMK N 3 SUKOHARJO, dari data yang diperoleh pelaksanaan simulasi di SMK N 3 SUKOHARJO sudah terlaksana sebanyak 2 kali, kegiatan ini sangat penting karena memberi kesempatan kepada siswa untuk mengetahui kesiapannya dalam menghadai UN. Siswa yang pada saat simulasi hasilnya belum memuaskan akan belajar lebih giat lagi, supaya mendapatkan nilai yang lebih baik, sementara bagi mereka yang simulasinya sudah baik akan merasa lebih tenang dan percaya diri untuk menghadapi UN. Selain mempersiapkan fasilitas,materi dan mental juga dilakukan doa bersama oleh seluruh siswa kelas XII bersama para guru. Dengan demikian diharapakan UNBK dapat berjalan dengan lancar dan mendapatkan hasil yang maksimal.

Tujuan dari kajian ini adalah (1) Untuk mengetahui seberapa besar upaya sekolah-sekolah dalam menghadapi UNBK. (2) Untuk mengetahui persiapan yang bisa dilakukan oleh siswa dalam mengadapi UNBK secara maksimal.

\section{METODE}

\section{Waktu}

Penulisan artikel ilmiah dilakukan selama kurang lebih dua minggu yaitu pada tanggal 29 Januari sampai dengan 12 Februari 2019.

\section{Tempat}

Penulisan artikel ilmiah dilaksanakan di SMKN 3 Sukoharjo di Jalan Telukan, Jawa Tengah, Indonesia.

\section{Desain Penelitian}

Dalam penelitian ini, penulis menggunakan pendekatan kualitatif. Menurut Sugiyono (dalam Chandra, 2016) penelitian kualitatif adalah suatu metode penelitian yang berlandaskan pada filsafat postpositivisme, digunakan untuk meneliti pada kondisi objek yang alamiah dimana peneliti adalah sebagai instrument kunci, pengambilan sample sumber data dilakukan secara purposive, Teknik pengumpulan data dengan triangulasi, analisis data bersifat induktif/kualitatif, dan hasil penelitian kualitatif lebih menekankan makna daripada generalisasi. Penelitian kualitatif bertumpu pada latar belakang alamiah secara induktif, lebih mementingkan proses daripada hasil serta hasil penelitian yang dilakukan disepakati oleh penelitian dan subjek penelitian.

Dipilih pendekatan kualitatif dalam penelitian ini didasarkan pada alasan bahwa permasalahan yang dikaji di dalam penelitian ini yaitu bagaimana intensi yang dimiliki oleh pensiun untuk mengikuti 
kegiatan/organisasi sosial untuk mengisi kehidupan sehari-harinya memerlukan sejumlah data lapangan yang bersifat actual dan konseptual. Di samping itu, pendekatan kualitatif lebih peka dan lebih dapat menyesuaikan diri dengan banyak penajaman pengaruh Bersama terhadap pola-pola nilai yang dihadapi dan situasi yang berubah-ubah selama penelitian berlangsung.

\section{Teknik Pengumpulan Data}

Adapun cara atau teknik yang dilakukan dalam usaha mengumpulkan semua data yang diperlukan dalam penelitian ini sebagai berikut:

a. Studi Kepustakaan yaitu teknik pengumpulan data yang bersumber dari buku-buku pelajaran atau literature yang terdapat mengenai teori-teori dan informasi yang berhubungan dengan materi artikel ilmiah yang sedang dilakukan saat ini.

b. Terjun lapangan adalah metode yang didapatkan melalui hasil langsung terjun ke tempat diadakannya observasi. Adapun metode lapangan dalam memperoleh data yang diperlukan.

\section{HASIL DAN PEMBAHASAN}

Hasil observasi yang telah dilakukan di SMK Negeri 3 Sukoharjo diharapkan untuk para pembaca mudah memahami hasil observasi yang telah dilakukan penulis dalam upaya-upaya SMK Negeri 3 Sukoharjo dalam menghadapi UNBK tahun 2019. Adapun langkahlangkah yang dilakukan penulis dalam melakukan observasi pada proses penganalisisan data yang akan disajikan kemudian data tersebut penulis analisis untuk mendapatkan data yang valid. Selain itu penulis juga mengajukan beberapa pertanyaan kepada informan untuk lebih mendapatkan hasil yang akurat.

Tabel 1. Guru Informan

\begin{tabular}{|c|l|c|}
\hline No & \multicolumn{1}{|c|}{ Nama } & Jabatan \\
\hline 1. & Suroto,S.Pd, M.Si & Wakil Kepala Sekolah \\
\hline 2. & Sari Sunaryati, S.Pd & Guru Akuntansi \\
\hline 3. & Hasri Munadi, S.Pd & Guru Akuntansi \\
\hline 4. & Nurjannah Wulan Asri, S.Pd & Guru Akuntansi \\
\hline 5. & Dra. Titik Sumarsih, M.Si & Guru Akuntansi \\
\hline
\end{tabular}

Sumber: informan guru SMKN 3 Sukoharjo

Tabel 2. Murid Informan

\begin{tabular}{|c|l|c|}
\hline No & \multicolumn{1}{|c|}{ Nama } & Jabatan \\
\hline 1. & Ari Setyono & Kelas XII TKR \\
\hline 2. & Novaldo & Kelas XII TKR \\
\hline 3. & Ega Pramudita & Kelas XII TKR \\
\hline 4. & Rahmad & Kelas XII TKR \\
\hline 5. & Verbiyan & Kelas XII TKR \\
\hline
\end{tabular}


Dari data diatas penulis mendapatkan informasi bahwa SMK Negeri 3 Sukoharjo dalam menghadapi UNBK telah melakukan beberapa kegiatan seperti :

1. Mengadakan simulasi UNBK yang sudah terlaksana sebanyak 2 kali.

2. Mengadakan jam pelajaran tambahan pada mata pelajaran yang akan diujiankan seperti Matematika, Bahasa Indonesia, Bahasa Inggris dan juga mata pelajaran sesuai dengan jurusan siswa.

3. Pemberian materi-materi dan kumpulan soal-soal UN kepada siswa agar lebih fokus pada materi.

4. Mengadakan sosialisasi menjelang UN kepada orang tua siswa.

5. Melaksanakan shalat dhuha pada kelas XII yang dilaksanakan setiap hari.

6. Mengadakan try out dan pembahasan soal-soal UN pada tahun sebelumnya.

Dari beberapa upaya yang dilakukan siswa merasa sangat terbantu dalam belajar sehingga lebih mudah memahami materi dan mempermudah dalam belajar. Hasil dari wawancara dengan guru sebagai berikut ini. Kesiapan guru dalam menghadapi pelaksanaan ujian nasional berbasis computer. Berdasarkan wawancara yang dilakukan mengenai kesiapan guru menghadapi pelaksanaan ujian nasional berbasis computer di SMK Negeri 3 Sukoharjo. Guru telah dibekali dan dilatih untuk menulis soal- soal klasifikasi materi-materi UN guru dibimbing membuat naskah dengan bedah kisi-kisi dan kemudian membuat soal, ini dilakukan oleh guru-guru bidang studi yang diujikan dan kemudian soal-soal tersebut dilatihkan kepada siswa/peserta didik agar mudah paham dan terbiasa dengan soal- soal UN. Pembelajaran oleh guru juga dibuat secara berfariatif menggunakan power point, video materi yang diberikan juga harus sesuai dengan materi yang akan diujikan pada UN.

Berdasarkan hasil wawancara siswa/peserta didik yang dilakukan peneliti yaitu dengan menggunakan Teknik wawancara mendalam yang terkait dengan persiapan sekolah dalam mengoptimalisasi UNBK di SMK Negeri 3 Sukoharjo dapat dikatakan baik dalam kesiapan dalam menghadapi pelaksanaannya. Berdasarkan wawancara sebagai berikut: (1) kesiapan siswa/peserta didik, kesiapan siswa dalam menghadapi pelaksanaan UNBK, (2) kesiapan siswa/peserta didik, kesiapan siswa dalam menghadapi ujian praktek kejuruan.

\section{SIMPULAN}

Upaya yang telah dilakukan oleh pihak sekolah dalam menghadapi UNBK sudah dipersiapkan secara matang dengan memperhatikan segala aspek yang berkaitan agar pelaksanaan UNBK berjalan dengan lancar dengan memberikan beberapa pelaksanaan simulasi UNBK. Sedangkan persiapan yang dilakukan oleh siswa juga sangat optimal mengingat para siswa juga menginginkan hasil yang 
maksimal dalam pelaksanaan UNBK tersebut.

\section{DAFTAR PUSTAKA}

Alawiyah, Farida. 2015. Perubahan Kebijakan Ujian Nasional (Studi Pelaksanaan Ujian Nasional 2015). Jurnal Aspirasi. Vol. 6, No. 2. Hlm. 189-202.

Chandra, Riandi., Maryam Mangantar \& Sem G oroh. 2016. Analisis Kinerja Keuangan PT Bank Syariah Mandiri Dan PT Bank Mandiri Tbk Dengan Menggunakan Metode Camel. Jurnal Berkala Ilmiah Efisiensi. Vol. 16, No. 2, Hlm. 429-435.

Firmansyah, Adi Udi. Aplikasi Simulasi Uji Coba (Tryout) Ujian

Nasional Berbasis Komputer (Unbk) Tahun 2018. Seminar Nasional Royal 2018. Sumatra Utara: 3 September 2018. Hlm. 111-114.

Hidayat, Nurdin., Ambyah Harjanto. \& Vetri Yanti Zainal. 2017. Memotivasi Siswa Sma Adiguna Bandar Lampung Dalam Mengikuti Ujian Nasional Berbasis Komputer (UNBK). Jurnal Pengabdian dan Pemberdayaan Masyarakat. Vol. 2, No. 1, Hlm. 1-4.

Jana, Padrul \& Andi Dian Rahmawan. 2019. Pendampingan Persiapan Ujian Nasional Berbasis Komputer Pada Siswa Sma Muhammadiyah 3 Yogyakarta. Jurnal Berdaya Mandiri. Vol. 1, No. 1, Hlm. 84-89.

Mardiana \& Febria Sri Handayani. Analisis Kesiapan Pelaksanaan Ujian Nasional Berbasis Komputer (UNBK) Pada Smkn Kota Palembang. Seminar Nasional Teknologi Informasi, Bisnis dan Desain. Palembang: 12 Juli 2017. Hlm. 283-288.

Negara, Habibi R.P., Farah H. Santosa \& Samsul Bahri. 2017. Peningkatan Kompetensi Ict Guna Simulasi Unbk Siswa Mts Nurul Ihsan Kecamatan Jonggat Kabupaten Lombok Tengah. Jurnal Masyarakat Mandiri. Vol. 1, No. 1, Hlm. 1-9.

Pakpahan, Rogers. 2016. Model Ujian Nasional Berbasis Komputer: Manfaat dan Tantangan. Jurnal Pendidikan dan Kebudayaan. Vol. 1, No. 1, Hlm. 19-36.

Sakethi, Dwi., Irwan Adi Pribadi \& Ririn Destiana. 2014. Pengembangan Sistem Simulasi Ujian Nasional Sekolah Menengah Atas (SMA) Online Berbasis Web. Jurnal Komputasi. Vol. 2, No. 2, Hlm. 109-114.

Sastradiharja, EE Junaedi. 2018. Manajemen Sekolah Berbasis Mutu. Jurnal Mumtaz. Vol. 2, No. 2. Hlm. 267-292.

Sulistyo, Gunadi H. 2007. Ujian Nasional (UN): Harapan, Tantangan, dan Peluang. Jurnal Wacana. Vol. 9, No. 1, Hlm. 79-106. 